\title{
Respon Fisiologis Sapi Fries Holland Laktasi yang Diberi Ransum dengan Konsentrat Mengandung Kulit Durian (Durio zibethinus) Difermentasi Pleorotus ostreatus
}

\author{
Physiological Response of Lactating Fries Holland Fed Ration with Concentrate \\ Containing Durian (Durio zibethinus) Peel meal Fermented with Pleorotus ostreatus
}

\author{
E. Sulistyowati, D. Suherman, I. Badarina, S. Mujiharjo dan S. Fanhar
}

Jurusan Peternakan, Fakultas Pertanian, Universitas Bengkulu

Jl. WR. Supratman, Kandang Limun, Bengkulu

Corresponding e-mail : ensulistyowati@yahoo.com

\begin{abstract}
This study aims to evaluate the administration of concentrates containing Fermented Durian peel meal (as KDF) in rations on dry matter intake and physiological conditions of lactating Fries Holland (FH) dairy cows. The design used was the Latin Square Design (LSD), with four treatments, KDF0: ration with concentrate without $\mathrm{KDF}(0 \%), \mathrm{KDF} 10$ : ration with $10 \% \mathrm{KDF}$ concentrate, $\mathrm{KDF} 20$ : ration with $20 \% \mathrm{KDF}$ concentrate, and KDF30 ration with $30 \% \mathrm{KDF}$ concentrate. The dairy cows used had an average body weight of $444.81 \pm 17.21 \mathrm{~kg}$. This research was carried out for four periods with 14 days per period and 14 preliminary days, a total of 70 days, housed in dairy farms in Suka Sari village, Kabawetan sub-district, Kepahiang Regency, Bengkulu province. Variables observed included dry matter consumption, barn environmental conditions (temperature and humidity) and physiological responses (respiration frequency, heart rate, and rectal temperature), observed in the morning, afternoon, and evening. The results showed that the environment temperature (temperature and humidity) of the barn at the time of the study were still in normal conditions for lactation dairy cows, and feeding containing concentrates with fermented durian peel meal up to level of $30 \%$ had no effect on respiration frequency, heart rate, rectal temperature, and dry matter intake.
\end{abstract}

Key words: fermented Durian peel meal, physiological responses, FH dairy cows

\begin{abstract}
ABSTRAK
Penelitian ini bertujuan untuk mengevaluasi pemberian konsentrat yang mengandung Kulit Durian Fermentasi (KDF) dalam ransum terhadap konsumsi bahan kering dan kondisi fisiologis sapi perah Fries Holland (FH) laktasi. Rancangan yang digunakan adalah Rancangan Bujur Sangkar Latin (RBSL), dengan empat perlakuan, KDF0: ransum dengan konsentrat tanpa $\mathrm{KDF}(0 \%)$, KDF10: ransum dengan konsentrat $10 \% \mathrm{KDF}$, KDF20: ransum dengan konsentrat $20 \% \mathrm{KDF}$, dan KDF30 ransum dengan konsentrat $30 \% \mathrm{KDF}$. Sapi perah yang digunakan mempunyai bobot badan rataan sebesar $444.81 \pm 17.21 \mathrm{~kg}$. Penelitian ini dilaksanakan selama empat periode dengan 14 hari per periode dan 14 hari pendahuluan, total 70 hari, bertempat di peternakan sapi perah di desa Suka Sari, kecamatan Kabawetan, Kabupaten Kepahiang, propinsi Bengkulu. Variabel yang diamati meliputi konsumsi bahan kering, kondisi lingkungan kandang (suhu dan kelembaban) dan respon fisiologi (frekuensi respirasi, denyut jantung, dan suhu rektal), diamati pada pagi, siang, dan sore. Hasil penelitian menunjukkan bahwa suhu lingkungan (suhu dan kelembaban) kandang pada saat penelitian masih dalam kondisi normal untuk sapi perah laktasi, dan pemberian pakan yang mengandung konsentrat dengan kulit durian fermentasi sampai level $30 \%$ tidak berpengaruh pada frekuensi respirasi, denyut jantung, suhu rektal, dan konsumsi bahan kering pakan.
\end{abstract}

Kata Kunci: Kulit durian fermentasi, respon fisiologi, sapi perah FH

\section{PENDAHULUAN}

Pengaruh lingkungan, khususnya temperatur dapat menurunkan produktivitas dan kenyamanan ternak. Oleh karena itu, untuk melindungi ternak dari stres panas (heat stress), penyediaan ransum yang sesuai dengan minimum kebutuhan adalah sangat penting. Sapi perah adalah jenis ternak yang sensitif terhadap stress akibat panas.

Sulistyowati (1991) melaporkan bahwa temperatur lingkungan yang tinggi dapat menurunkan konsumsi bahan kering, 
meningkatkan konsumsi air minum, meningkatkan kandungan protein susu, serta meningkatkan temperatur rektal juga frekuensi pernapasan sapi perah selama musim panas di daerah subtropis. Ditambahkan, bahwa suplementasi mineral $\mathrm{NaCl}, \mathrm{KCl}$, dan $\mathrm{KHCO} 3$ tidak berpengaruh terhadap konsumsi air minum dan variabel fisiologis. Menurut Santosa (2008) pemberian pakan biasanya secara bertahap pada pagi dan sore dengan pemberian yang dibatasi. Pemberian pakan dengan level yang berbeda akan mempengaruhi kondisi fisiologi ternak seperti suhu rektal, frekuensi respirasi dan denyut jantung yang diakibat proses metabolisme dalam tubuh (Naidin et al., 2010).

Upaya untuk mengurangi efek negatif dari stres panas lingkungan pada sapi perah antara lain melalui modifikasi nutrisi seperti pemberian mineral dan mengurangi kandungan serat kasar dalam ransum sehingga panas metabolis yang dihasilkan tidak menambah efek stres panas pada ternak.

Buah durian merupakan limbah pertanian yang berpotensi menjadi sumber pakan alternatif untuk mengembangkan usaha peternakan. Buah Durian (Durio zibethinus) merupakan tumbuhan tropis yang tumbuh subur di Indonesia. Produksi buah durian di Provinsi Bengkulu tahun 2010 sekitar 50,4 ton/tahun (BPS, 2012). Buah durian terdiri dari daging buah sekitar 20$25 \%$, biji sekitar $5-15 \%$, dan sisanya berupa bobot kulit mencapai 60-70\% (Suhaidi, 2004). Berdasarkan penelitian sebelumnya (Sulistyowati et al., 2018 ), kulit durian mengandung serat kasar yang cukup tinggi $(32,13 \%)$, untuk itu perlu dilakukan fermentasi untuk mengurai ikatan lignin dan silica menjadi sumber energy yang lebih mudah dicerna.

Sangadji et al. (2008) menyatakan bahwa proses fermentasi menggunakan jamur Pleurotus ostreatus dapat diterapkan dalam pengolahan limbah pertanian. Jamur Pleurotus osreotus ini juga mengandung senyawa aktif berupa $\beta$ glucan yang berfungsi sebagai suplemen karena aktivitas immunomodulator polisakarida yang dapat merangsang pertumbuhan mikroorganisme usus sebagai prebiotik (Widyastuti et al., 2011).

Pemanfaatan limbah dari media jamur Pleurotus ostreatus dapat meningkatkan protein kasar dan menurunkan kadar serat kasar selama masa inkubasi (Johan, 2014), Badarina et al. (2013), menyatakan bahwa limbah kulit kopi yang difermentasi oleh jamur Pleurotus ostreatus mampu meningkatkan protein kasar dari 10,36 menjadi $12,14 \%$ serta menurunkan kadar hemiselulosa, lignin, tanin dan kafein. Jamur Pleurotus ostreatus merupakan salah satu jamur yang dapat mendegradasi ikatan lignin lebih ektensif dibandingkan mikrooganisme yang lain, karena jamur ini dapat memproduksi enzim ligninolitic extracellular, seperti laccases, lignin peroxidases dan Mn peroxidases (Hatakka, 1994).

Berdasarkan uraian diatas, maka penelitian ini dilakukan bertujuan untuk mengevaluasi pengaruh pemberian tepung kulit durian (Durio zibethinus) yang difermentasi Pleorotus ostreatus terhadap respon fisiologis sapi perah FH laktasi.

\section{MATERI DAN METODE}

Penelitian ini dilakukan selama 70 hari dimana 14 hari masa adaptasi dan 56 hari masa perlakuan di Desa Suka Sari Kecamatan Kabawetan Kabupaten Kepahiang Provinsi Bengkulu. Daerah ini merupakan dataran tinggi dengan rataan suhu harian sekitar $21.7^{\circ} \mathrm{C}$.

Persiapan Kulit Durian Fermentasi (KDF) dilakukan berdasarkan prosedur pada Sulistyowati et al. $\left(2018^{\mathrm{a}}\right)$, yaitu pembuangan kulit luar, pengirisan kulit dalam, penjemuran, penggilingan menjadi tepung, fermentasi. Proses fermentasi diawali dengan mencampur bahan $85 \%$ kulit durian, $13 \%$ dedak padi, dan $2 \% \mathrm{CaCO}_{3}$, kemudian dicampur dengan air sebanyak 90\%; setelah itu dikomposkan selama 3 hari, ditimbang sekitar 500g campuran tersebut ke dalam baglog, disterilisasi dengan 
pengukusan pada suhu $120^{\circ} \mathrm{C}$ selama 4 jam, didinginkan, diinokulasi dengan Pleurotus ostreatus sebanyak $0,5 \%$.

Pembuatan tepung temulawak (Curcuma xanthorrhiza) dimulai dengan membersihkan rimpang temulawak, mencuci, mengiris tipis, menjemur di bawah panas matahari sampai kering, menggiling menjadi tepung. Ragi tape dibuat dengan modifikasi prosedur Pusbangtepa, 1981.

Formula konsentrat sesuai perlakuan disusun berdasarkan prosedur Sulistyowati et al. $\left(2018^{\mathrm{b}}\right)$, yaitu dedak padi dan kulit durian fermentasi mempunyai perlakuan imbangan $30 / 0,20 / 10,10 / 20,0 / 30 \%$, berturut- turut untuk KDF0, KDF10, KDF20, dan KDF30; dan jagung 30\%, kedelai giling 32\%, minyak sawit 3,5\%, mineral mix $0,5 \%$, temulawak $1,5 \%$, ragi tape $1 \%, \mathrm{NaCl} 0,5 \%, \mathrm{CaCO}_{3}$ $0,5 \%$, dan TSP $0,5 \%$. Konsentrat dengan $\mathrm{KDF}$ ini diberikan sebanyak $2 \mathrm{~kg} /$ ekor/hari, $1 \mathrm{~kg}$ pagi dan $1 \mathrm{~kg}$ sore. Selain itu ada konsentrat yang biasa diberikan oleh peternak (Surya feed) sebanyak 4 $\mathrm{kg} / \mathrm{ekor} / \mathrm{hari}$.

Pakan hijauan sebanyak $35 \mathrm{~kg} / \mathrm{ekor} /$ hari yang terdiri atas King grass $(40 \%)$, daun jagung (40\%) dan jerami padi (20\%), ditimbang pemeberian dan sisanya untuk menghitung konsumsinya. Air minum diberikan ad lib. namun diukur jumlah konsumsinya setiap hari.

Kandungan bahan kering konsentrat dengan tepung kulit durian yang difermentasi $P$. ostreatus dan hijauan yang diberikan pada sapi perah laktasi, berturut- turut adalah KDF0 (89,74\%), KDF 10 (87,72\%), KDF20 $(76,42 \%)$, KDF $30 \quad(70,58 \%)$, konsentrat Surya feed $(85.88 \%)$, jerami jagung $(24,77 \%)$ dan jerami padi $(20,14 \%)$.

\section{Suhu Rektal $\left({ }^{\circ} \mathrm{C}\right)$}

Pengukuran suhu rektal dengan menggunakan thermometer yang dimasukkan ke dalam rektal sapi perah ketika ternak sapi perah dalam keadaan tenang selama \pm 10 menit sebelum alat thermometer dimasukkan ke dalam rektal, alat thermometer rektal dimasukkan sedalam $\pm 8 \mathrm{~cm}$ dengan penghitungan waktu menggunakan stopwatch selama \pm 3-5 menit.

\section{Denyut jantung (kali/menit)}

Pengukuran denyut jantung dilakukan dengan menggunakan stetoskop yang di dekat pada tulang axilla sebelah kiri (dada sebelah kiri), dilakukan selama satu menit dengan menggunakan alat stopwatch dengan tiga kali ulangan setiap pengukuran. Respirasi diukur setelah dilakukan pengukuran detak jantung.

\section{Frekuensi respirasi (kali/menit)}

Pengukuran respirasi dilakukan dengan cara menempelkan telapak tangan bagian luar kemudian letakkan di depan hidung sapi, lama pengukuran selama satu menit dengan menggunakan alat stopwatch. Pengukuran fisiologis ini dilakukan pada pagi, siang, dan sore hari

\section{Suhu lingkungan $\left({ }^{0} \mathrm{C}\right)$ dan kelembaban (\%)}

Suhu lingkungan pada setiap kandang diukur dengan menggunakan termometer. Pengukuran dilakukan pada pagi, siang, dan sore. Suhu lingkungan yang terlibat pada termometer dicatat sebagai suhu lingkungan.

Kelembaban pada setiap kandang diukur dengan menggunakan termometer bola basa dan bola kering. Pengukuran dilakukan pada pagi, siang, dan sore. Angka yang terlihat pada termometer dicatat sebagai kelembaban.

Temperature humidity index (THI) merupakan pengukuran tingkat stres pada ternak yang dapat dipengaruhi oleh suhu lingkungan dan faktor pakan. Menurut Dobson et al. (2003) suhu dan kelembaban udara memiliki hubungan yang dapat mempengaruhi kenyamanan hidup ternak. Sapi perah jenis Friesian Holstein (FH) dapat hidup dengan nyaman pada nilai THI dibawah 71. Apabila interaksi ini melebihi batas ambang ideal hidup ternak, bisa menyebabkan terjadinya cekaman/stress panas. pengukur THI pada ternak dapat dilakukan dengan rumus $\mathrm{THI}=\mathrm{DBT}+0,36$ WBT + 41,2 (Hahn, 1999). 
Keterangan:

$\mathrm{DBT}=$ Suhu bola kering $(\mathrm{C})$

WBT $=$ Suhu bola basah $(\mathrm{C})$

\section{Analisis data}

Penelitian ini menggunakan Rancangan Bujur Sangkar Latin (RBSL) 4 X 4 dengan menggunakan 4 perlakuan, 4 periode, dan 4 ekor sapi perah laktasi, dimana dalam 1 periode adalah 14 hari perlakuan dengan melakukan adaptasi selama 14 hari dan analisis data yang digunakan sidik ragam (ANOVA). Apabila analisis berpengaruh nyata $(\mathrm{P}<0.05)$ maka dilanjutkan dengan Uji Duncan's Multiple Range Test (DMRT) menurut Lentner dan Bishop (1986).

\section{HASIL DAN PEMBAHASAN}

\section{Deskripsi Peternakan Rakyat di Kecamatan Kabawetan Kabupaten Kepahiang.}

Menurut data BMKG (2019)

Kecamatan Kabawetan berada di sebelah Selatan berbatasan dengan Kecamatan Taba Penanjung Kabupaten Bengkulu Tengah, sebelah Barat berbatasan dengan Kecamatan Pagar Jati Kabupaten Bengkulu Utara, sebelah Utara berbatasan dengan Kecamatan Curup Kabupaten Rejang Lebong, dan sebelah Timur berbatasan dengan kecamatan Ulu Musi Kabupaten Lahat Provinsi Sumatera Selatan. luas wilayah Kecamatan Kabawetan yaitu $250 \mathrm{~km}^{2}$, dengan ketinggian \pm 1.600 meter di atas permukaan laut dengan curah hujan rata-rata $233,5 \mathrm{~mm} / \mathrm{bulan}$. Suhu udara harian rata-rata berkisar $23,87^{\circ} \mathrm{C}$, dengan suhu maksimal $29,87{ }^{\circ} \mathrm{C}$ dan suhu minimum $19,65{ }^{\circ} \mathrm{C}$ dan kelembaban udara rata-rata $85,21 \%$.

\section{Kondisi lingkungan kandang}

Table 1. Rataan suhu dan kelembaban dalam kandang selama penelitian

\begin{tabular}{cccc}
\hline Waktu & Suhu $\left({ }^{0} \mathrm{C}\right)$ & Kelembaban $(\%)$ & THI \\
\hline Pagi & $20 \pm 0,28$ & $93 \pm 2,75$ & $68 \pm 0,42$ \\
Siang & $25 \pm 0,75$ & $86 \pm 7,83$ & $75 \pm 1,29$ \\
Sore & $24 \pm 1,55$ & $89 \pm 6,88$ & $73 \pm 2,32$ \\
\hline
\end{tabular}

Salah satu parameter yang diamati dalam penelitian yaitu kondisi lingkungan. Lingkungan merupakan faktor eksternal nongenetik yang dapat mempengaruhi respon dan pertumbuhan ternak (Esmay 1978). Lingkungan yang diamati dalam penelitian ini terdiri atas suhu lingkungan, kelembaban udara, dan THI. Pengamatan dilakukan 3 kali mulai pukul $06.00,12.00$, dan 16.00 yang disajikan pada Tabel 1 .

Hasil penelitian menunjukkan kecenderungan perbedaan hasil pengukuran lingkungan mikroklimat antara pagi, siang, dan sore. Suhu lingkungan kandang pada saat penelitian berkisar $20-25^{\circ} \mathrm{C}$ dengan kelembaban berkisar $86-93 \%$. Suhu lingkungan dalam kandang selama penelitian didapatkan hasil suhu udara minimum pada pengamatan pagi hari sebesar $20 \pm 0,28^{\circ} \mathrm{C}$ dan kelembaban maksimum $86 \pm 7,83 \%$ pada saat pengukuran siang hari, sedangkan suhu udara maksimum pada pengamatan siang hari sebesar $25 \pm 0,75^{\circ} \mathrm{C}$ dan kelembaban minimum $93 \pm 2,75 \%$ pada saat pengukuran pagi hari. Meningkatnya suhu dan kelembaban tersebut, mengakibatkan proses penguapan dari tubuh sapi perah akan terhambat sehingga dapat mengalami cekaman panas. Suhu lingkungan merupakan factor yang mempengaruhi produksi sapi perah, karena dapat menyebabkan perubahan keseimbangan panas dalam tubuh ternak (Esmay dan Dixon, 1986).

Rataan suhu udara dalam kandang pada pagi dan sore, masing-masing menunjukkan kisaran antara $20^{\circ} \mathrm{C}$ dan $24^{\circ} \mathrm{C}$. Hasil penelitian tersebut, baik pada suhu pagi maupun sore masih dalam kondisi normal. Kondisi lingkungan tersebut dikatakan dalam kondisi nyaman dan tidak menyebabkan stress pada ternak sapi FH (Sudono et al., 2003). 
Siang hari rataan suhu udara dalam kandang menunjukkan kisaran antara $25^{\circ} \mathrm{C}$. Hasil penelitian menunjukkan bahwa suhu udara dalam kandang pada siang hari lebih tinggi dari pada pagi dan sore hari. Nilai suhu udara antara $15-25^{\circ} \mathrm{C}$ menunjukkan kondisi lingkungan tidak memberikan cekaman pada ternak sapi perah. Kisaran zona yang memberikan cekaman pada ternak sapi perah berada pada suhu udara $27^{\circ} \mathrm{C}$ pada suhu udara lingkungan tersebut sapi akan memperlihatkan penampilan produksi semakin menurun seiring dengan peningkatan suhu lingkungan yang melebihi zona thermoneutral (Suherman et al., 2013).

Kelembaban udara dalam kandang yang diukur langsung pada pagi, siang, dan sore hari. Data rataan kelembaban udara pada saat penelitian berkisaran antara 86-93\%. Hasil penelitian menunjukkan bahwa kelembaban udara lebih tinggi dari kelembaban udara ideal untuk lingkungan hidup sapi perah. Tingginya kelembaban udara dapat menyebabkan ternak melakukan penyesuaian secara fisiologis dan secara tingkah laku untuk mengurangi cekaman (Yani dan Purwanto, 2006).

Suhu dan kelembaban udara dapat dinyatakan dalam bentuk indeks suhu dan kelembaban udara atau Temperature Humidity Index (THI). Selain itu Indeks juga digunakan untuk mengetahui adanya cekaman panas karena keadaan lingkungan yang tidak nyaman. Adanya stress panas yang dipengaruhi oleh kondisi lingkungan dapat menyebabkan terganggunya produktivitas ternak karena metabolisme tubuh tidak sama dengan kondisi ternak dalam lingkungan yang nyaman.

Kondisi lingkungan selama penelitian pada pagi hari memiliki rataan suhu lingkungan sebesar $20-25^{\circ} \mathrm{C}$ dengan THI sebesar 68-75. Berdasarkan penelitian yang telah dilakukan diperoleh data Temperature Humidity Index (THI) berkisar 68-75. THI dalam kandang selama penelitian didapatkan hasil THI minimum pada pengamatan pagi hari sebesar $68 \pm 0,42$ dan THI maksimum $75 \pm 2,32$ pada saat pengukuran siang hari.
Sapi perah dapat hidup dengan nyaman apabila THI dibawah 72 (Bohmanova et al., 2007)

Suhu berkisar $24-34^{\circ} \mathrm{C}$ dan kelembaban $60-90 \%$ berpengaruh tinggi terhadap tingkat produktivitas sapi $\mathrm{FH}$ di Indonesia. Untuk sapi perah $\mathrm{FH}$, penampilan produksi terbaik akan dicapai pada suhu $18,3^{\circ} \mathrm{C}$ dengan kelembaban 55\% (Yani dan Purwanto, 2006). Sapi perah akan hidup nyaman, tanpa stress jika hidup pada suhu lingkungan sekitar $10-20^{\circ} \mathrm{C}$, yang merupakan thermo neutral zone (TNZ) menurut Larson (1985).

Berdasarkan Tabel 1 dapat dilihat dimana suhu pada pagi hari baik di lingkungan kandang sekitar $20^{\circ} \mathrm{C}$ meningkat di siang hari mencapai $25^{\circ} \mathrm{C}$ dan turun pada suhu $24^{0} \mathrm{C}$, dengan THI pada pagi hari sekitar 68 kemudian meningkat mencapai 75 pada siang hari dan menurun mencapai 73 pada sore hari. Temperatur normal sapi akan merasa nyaman apabila nilai THI di bawah $\leq$ 72 , apabila nilai $\mathrm{THI} \geq 72$ (72-79), maka sapi tersebut akan mengalami stress ringan, nilai THI $\geq 79$ (80-89), maka sapi akan mengalami stress sedang dan apabila nilai THI $\geq 89$ (90-99), maka sapi tersebut akan mengalami stress berat. Menurut Chase (2006), pada suhu $20^{\circ} \mathrm{C}$ dan THI 68 $(\mathrm{THI} \leq 72)$ sapi perah dalam keadaan nyaman dan tidak menyebabkan stress. Pada siang hari dengan suhu maksimal berkisar $25^{\circ} \mathrm{C}$ dan THI 75, sedangkan pada sore hari suhu $24^{\circ} \mathrm{C}$ dan THI 73 (THI $\geq 72$ ). Pada kondisi tersebut sapi dalam kondisi stress ringan yang bisa menyebabkan peningkatan produksi saliva serta laju pernafasan, nafsu makan menurun dan minum akan meningkat, selektif mengurangi hijauan, relatif memilih konsentrat untuk mengurangi suhu tubuh melalui pengurangan produksi panas dari fermentasi, pencernaan dan proses metabolisme lainnya (Beede dan Collier 1986). Namun rataan harian nilai THI pada lingkungan kandang menunjukan kisaran 72 , sehingga dapat dikatakan bahwa Temperature Humidity Index (THI) dilokasi 
kandang memiliki temperatur normal untuk pemeliharaan sapi perah FH.

\section{Konsumsi bahan kering (BK) pakan}

Hasil penelitian konsumsi Bahan Kering (BK) pada pakan sapi perah FH laktasi dengan perlakuan pemberian konsentrat kulit durian fermentasi, konsentrat peternak (Surya feed), dan pakan hijauan pada setiap perlakuan disajikan pada Tabel 2.

Berdasarkan analisis sidik ragam menunjukan bahwa perlakuan yang mengandung konsentrat kulit durian fermentasi tidak berpengaruh nyata $(\mathrm{P}>0,05)$ terhadap konsumsi bahan kering. Hal tersebut membuktikan bahwa pemberian konsumsi bahan kering yang berupa kulit durian fermentasi, konsentrat peternak (Surya feed), dan hijauan tidak memberikan pengaruh terhadap konsumsi pakan sapi perah FH laktasi.

Hasil penelitian yang tertera pada tabel 2 rataan konsumsi bahan kering tertinggi yaitu pada pemberian KDF0 sebanyak 15,16 kg/ekor/hari, konsumsi bahan kering terendah pada pemberian KDF30 sebanyak 14,66 kg/ekor/hari. Pakan yang mengandung konsentrat kulit durian fermentasi tidak mengalami kenaikan konsumsi secara signifikan tetapi dapat meningkatkan konsumsi bahan kering ransum. Menurut Davies (1982) bahwa konsumsi pakan dapat dipengaruhi oleh beberapa faktor antara lain palatabilitas, kualitas dan kuantitas ransum.

Konsumsi bahan kering hasil penelitian telah mencukupi standar kebutuhan untuk sapi perah laktasi, yaitu sebesar 3-4\% dari bobot badan. Hasil tersebut sesuai dengan penelitian Williamson dan Payne (1993) yang menyatakan bahwa konsumsi bahan kering sapi perah laktasi berkisar 2-4\% dari bobot badan. Menurut NRC (1989) menyatakan bahwa kebutuhan pemberian bahan kering yang direkomendasikan untuk sapi perah laktasi untuk berat badan $400 \mathrm{~kg}$ dengan produksi susu sebesar $10 \mathrm{~kg} /$ ekor/hari adalah 2,7\% dari bobot badan atau setara dengan 10,8 $\mathrm{kg} / \mathrm{ekor} / \mathrm{hari}$.

Konsumsi bahan kering ransum sebesar $21.3 \mathrm{~kg} /$ hari dengan produksi susu sekitar $26.8 \mathrm{~kg} / \mathrm{hari}$ pada sapi perah dengan rataan bobot badan rataan $552.95 \mathrm{~kg} / \mathrm{ekor}$ selama musim panas di daerah subtropis dengan suhu rataan $28.3^{\circ} \mathrm{C}$ (Sulistyowati, 1991). Rasio konsumsi bahan kering ransum terhadap bobot badan pada penelitian tersebut adalah 4,8\%. Secara terpisah, dilaporkan bahwa produksi susu sapi perah yang diberi ransum dengan konsentrat yang mengandung kulit durian fermentasi $20 \%$ menghasilkan produksi susu tertinggi $(11,52$ $\mathrm{kg} / \mathrm{ekor} / \mathrm{hari}$ ) dengan rasio terhadap bobot badan sebesar 3,8\% (Sulistyowati et al., 2018).

Tabel 2. Rataan konsumsi bahan kering (BK) ransum yang mengandung konsentrat KDF pada sapi perah laktasi

\begin{tabular}{lcccc}
\hline \multirow{2}{*}{ Variabel } & \multicolumn{4}{c}{ Perlakuan } \\
\cline { 2 - 5 } & KDF0 & KDF10 & KDF20 & KDF30 \\
\hline \multirow{2}{*}{ Konsumsi BK Hijauan } & $9,93 \pm 0,08$ & $9,86 \pm 0,16$ & $9,73 \pm 0,11$ & $9,81 \pm 0,09$ \\
Konsumsi BK Konsentrat & $1,79 \pm 0,00$ & $1,75 \pm 0,00$ & $1,53 \pm 0,00$ & $1,41 \pm 0,00$ \\
KDF & $3,44 \pm 0,00$ & $3,44 \pm 0,00$ & $3,44 \pm 0,00$ & $3,44 \pm 0,00$ \\
Konsumsi BK Surya Feed & $15,16 \pm 0,03$ & $15,05 \pm 0,11$ & $14,69 \pm 0,17$ & $14,66 \pm 0,18$ \\
\hline \multicolumn{1}{c}{ Total } &
\end{tabular}

Ket: Rataan konsumsi bahan kering (BK) setiap hari selama penelitian menunjukkan hasil tidak berpengaruh nyata $(\mathrm{P}>0,05)$ antar perlakuan. $\mathrm{KDF} 0: 0 \% \mathrm{KDF} / \mathrm{kg}$ konsentrat, $\mathrm{KDF} 10$ : dengan $10 \% \mathrm{KDF} / \mathrm{kg}$ konsentrat, $\mathrm{KDF} 20$ dengan $20 \% \mathrm{KDF} / \mathrm{kg}$ konsentrat, dan $\mathrm{KDF} 30$ : dengan $30 \% \mathrm{KDF} / \mathrm{kg}$ konsentrat. 


\section{Pengaruh pemberian konsentrat KDF terhadap respon fisiologis}

Pengukuran frekuensi respirasi, denyut jantung, dan suhu rektal bertujuan untuk mengetahui tingkat stress sapi perah terhadap cekaman panas dan pemanasan metabolisme yang disebabkan terhadap pemberian konsentrat kulit durian fermentasi, Hasil penelitian frekuensi respirasi, denyut jantung, dan suhu rektal disajikan pada Tabel 3. Pemberian konsentrat kulit durian fermentasi dalam ransum berpengaruh tidak nyata $(\mathrm{P}>0,05)$ terhadap frekuensi respirasi, denyut jantung, dan suhu rektal baik pagi, siang, maupun sore hari.

Perubahan suhu dapat mempengaruhi respon pada sapi perah yang dilihat melalui perubahan frekuensi respirasi, denyut jantung, dan suhu rektal yang merupakan mekanisme dari tubuh sapi perah untuk mengurangi atau melepaskan panas yang diterima dari luar tubuh ternak dan metabolisme dalam tubuh.

Ternak akan membuang panas dalam tubuhnya dengan cara proses respirasi, denyut jantung, dan suhu rektal untuk membuang atau mengganti panas dengan udara sekitarnya. Jika frekuensi respirasi, denyut jantung, dan suhu rektal pada ternak tidak berhasil mengurangi panas dari suhu lingkungan dan metabolisme, maka ternak mengalami cekaman panas karena suhu organ tubuhnya akan meningkat (Yani dan Purwanto, 2006).

\section{Frekuensi respirasi}

Hasil penelitian menunjukkan rataan respirasi pada saat penelitian yang tertera pada Tabel 3 berkisar antara 35-42 kali/menit. Nilai rataan tersebut masih dalam kisaran normal. Hal tersebut sejalan dengan hasil penelitian Sulistyowati (1991) yang mendapatkan rataan frekuensi respirasi meningkat dari 54,9 kali/menit (pada suhu $27,1^{\circ} \mathrm{C}$ ) menjadi $67,5 \mathrm{kali} / \mathrm{menit}$ (pada suhu $29,9^{\circ} \mathrm{C}$ ) pada sapi perah selama musim panas.

Rataan frekuensi respirasi pada pagi hari sebesar $35 \mathrm{kali} / \mathrm{menit}$ dengan suhu lingkungan $20^{\circ} \mathrm{C}$, peningkatan frekuensi respirasi terjadi pada siang hari sekitar 42 kali/menit dengan diiringi peningkatan suhu lingkungan sekitar $25^{\circ} \mathrm{C}$, sedangkan pada sore hari frekuensi respirasi menurun sekitar $39 \mathrm{kali} /$ menit dengan suhu lingkungan $24^{\circ} \mathrm{C}$. Tingginya frekuensi respirasi pada siang hari dapat disebabkan ketidak nyamanan akibat perubahan kondisi suhu lingkungan kandang. Rumetor (2003) menjelaskan bahwa meningkatnya frekuensi respirasi merupakan salah satu tanda sapi mengalami stress panas. Frekuensi pernapasan meningkat dari 54,9 kali per menit (pada suhu lingkungan $27,1^{\circ} \mathrm{C}$ ) menjadi 67,5 kali per menit (pada suhu lingkungan $29,9^{\circ} \mathrm{C}$ ) di daerah subtropis pada musim panas (Sulistyowati, 1991).

Tabel 3. Rataan frekuensi respirasi, denyut jantung, dan suhu rektal, yang mengandung konsentrat KDF pada sapi perah laktasi

\begin{tabular}{|c|c|c|c|c|c|c|}
\hline \multirow{2}{*}{ Variabel } & \multirow{2}{*}{ Waktu } & \multicolumn{4}{|c|}{ Perlakuan } & \multirow{2}{*}{ Prob } \\
\hline & & P0 & P1 & P2 & P3 & \\
\hline \multirow{3}{*}{$\begin{array}{c}\text { Respirasi } \\
\text { (kali/menit) }\end{array}$} & Pagi & $35 \pm 2,69$ & $36 \pm 3.79$ & $36 \pm 3.70$ & $36 \pm 3.05$ & 0,94 \\
\hline & Siang & $42 \pm 1.53$ & $42 \pm 1.34$ & $41 \pm 4.17$ & $41 \pm 3.10$ & 0,87 \\
\hline & Sore & $40 \pm 1.53$ & $40 \pm 1.41$ & $40 \pm 4.17$ & $39 \pm 2.34$ & 0,89 \\
\hline \multirow{3}{*}{$\begin{array}{c}\text { Denyut } \\
\text { jantung } \\
\text { (kali/menit) }\end{array}$} & Pagi & $62 \pm 1,05$ & $61 \pm 1,99$ & $61 \pm 1,36$ & $61 \pm 1,28$ & 0,68 \\
\hline & Siang & $65 \pm 0,58$ & $64 \pm 1,85$ & $65 \pm 0,35$ & $64 \pm 1,33$ & 0,46 \\
\hline & Sore & $65 \pm 0,58$ & $63 \pm 1,67$ & $64 \pm 0,31$ & $62 \pm 1,38$ & 0,50 \\
\hline \multirow{3}{*}{$\begin{array}{l}\text { Suhu Rektal } \\
\quad\left({ }^{\circ} \mathrm{C}\right)\end{array}$} & Pagi & $37,96 \pm 0,43$ & $37,95 \pm 0,34$ & $38,10 \pm 0.62$ & $37,95 \pm 0,48$ & 0,96 \\
\hline & Siang & $38,27 \pm 0,58$ & $38,28 \pm 0,25$ & $38,45 \pm 0.43$ & $38,30 \pm 0,49$ & 0,94 \\
\hline & Sore & $38,08 \pm 0,46$ & $38,15 \pm 0,29$ & $38,28 \pm 0.54$ & $38,11 \pm 0,50$ & 0,93 \\
\hline
\end{tabular}

Ket:Rataan frekuensi respirasi, denyut jantung, dan suhu rektal pada setiap hari selama penelitian menunjukkan hasil tidak berbeda nyata $(\mathrm{P}>0,05)$ antar perlakuan. KDF0: $0 \% \mathrm{KDF} / \mathrm{kg}$ konsentrat, KDF10: dengan 10\% $\mathrm{KDF} / \mathrm{kg}$ konsentrat, KDF20 dengan $20 \% \mathrm{KDF} / \mathrm{kg}$ konsentrat, dan $\mathrm{KDF} 30$ : dengan $30 \% \mathrm{KDF} / \mathrm{kg}$ konsentrat. 
Ternak dapat mengurangi panas dalam tubuh akibat pengaruh dari lingkungan dengan cara melakukan evaporasi. Evaporasi dapat terjadi pada ternak dengan peningkatan laju respirasi. Apabila suhu lingkungan meningkat, maka hewan harus mengeluarkan panas dalam tubuh dengan cara evaporasi yang dilakukan melalui peningkatan laju respirasi. Menurut Parakkasi (1999), pada daerah yang kering dengan kelembaban rendah, maka respirasi ternak terjadi lebih cepat. Peningkatan frekuensi respirasi dapat terjadi pada ternak untuk menjaga keseimbangan panas tubuh saat mengalami cekaman panas tubuh dari hasil metabolisme pakan dan cuaca lingkungan.

Pemberian kulit durian fermentasi sebagai konsentrat tidak mempengaruhi laju frekuensi respirasi ternak pada penelitian ini sebab pakan yang diberikan berada pada meintenan level atau sesuai dengan kebutuhan pokok dan produksi, selain itu rasio pakan hijauan lebih besar $60 \%$ dibandingkan rasio pakan konsentrat $40 \%$. West (2003) menjelaskan bahwa rasio pemberian pakan konsentrat yang lebih besar dibanding hijauan akan menghasilkan prosuksi yang tinggi. Laju frekuensi respirasi dapat menjadi salah satu indikator kesehatan dimana tinggi rendahnya frekuensi respirsi berkaitan langsung dengan proses metabolisme tubuh.

Laju frekuensi respirasi dapat terganggu pada ternak yang mengelami bloat. Rasio pemberian pakan konsentrat yang lebih besar dibandingkan hijauan juga dapat menyebabkab bloat. Hal ini disebabkan karena terjadi peningkatan gas hasil fermentasi pakan dalam rumen yang tidak dapat dikeluarkan dari tubuh. Divers dan Peek (2008) menjeleskan bahwa konsentrasi $\mathrm{CO}_{2}$ yang berlebih dapat menyebabkan frekuensi respirasi menjadi lambat, hal ini akan mengganggu kenyamanan ternak. Kandungan $\mathrm{CO}_{2}$ yang tinggi ini dapat menyebabkan asam basa terganggu dimana $\mathrm{CO}_{2}$ merupakan salah satu asam maka apabila tidak dikeluarkan dapat terjadi penimbunan asam dalam tubuh yang dapat mengganggu metabolisme tubuh.

\section{Denyut jantung}

Ternak yang terekspos temperatur suhu lingkungan yang tinggi atau rendah dapat menyebabkan meningkatnnya denyut jantung. Peningkatan suhu akan mempengaruhi jantung, juga dipengaruhi oleh penurunan tekanan darah yang berasal dari vasodilatasi periferal (Nikkhah et al., 2008). Proses terakhir yaitu peningkatan jumlah adrenalindan nonadrenalin yang disekresikan untuk membentuk energi, disertai sekresi hormon lainnya dari kelenjar endokrin, sehingga menyebabkan peningkatan denyut jantung (Tucker et al., 2008). Denyut jantung merupakan organ penting untuk mengalirkan darah ke berbagai jaringan. Isnaeni (2006) menjelaskan bahwa jantung sebagai pompa penggerak cairan bersirkulasi, sedangkan pembuluh darah berfungsi sebagai jalan aliran darah

Denyut jantung pada saat penelitian dapat dilihat pada Tabel 3 berkisar antara 61$65 \mathrm{kali} /$ menit. Nilai rataan tersebut masih dalam kisaran normal. Hasil penelitian Purwanto et al. (1993) yang mengemukakan bahwa rataan denyut jantung antara 52-76 kali/menit. Rataan denyut jantung pada pagi dan sore hari menunjukan bahwa masingmasing berkisar 61-62 dan 62-65.

Pemberian konsentrat kulit durian fermentasi tidak menunjukkan berdeda nyata pada denyut jantung. Denyut jantung ternak pada puncak cuaca panas terjadi siang (pukul 12.00) dengan suhu udara didalam kandang rata-rata berkisar $25^{\circ} \mathrm{C}$, yang diiringi dengan peningkatan denyut jantung ternak sekitar 64-65 kali/menit. Hasil penelitian tersebut menunjukkan bahwa sapi perah dalam kondisi normal dengan peningkatan suhu kandang. Ada kecenderungan sapi yang memperoleh perlakuan energi pakan konsentrat yang tinggi, menunjukkan denyut jantung yang tinggi pula. Hal tersebutberkaitan dengan aktivitas metabolisme sapi. Sapi yang memperoleh produksi panas yang tinggi mengakibatkan aktivitas metabolisme yang cepat dibandingkan pada sapi yang memperoleh produksi panas yang rendah. Isnaeni (2006) mengemukakan bahwa produksi panas yang 
tinggi cenderung meningkatkan denyut jantung, yang merupakan mekanisme untuk menjaga tekanan darah. Saat ada cekaman suhu udara $\left(32^{\circ} \mathrm{C}\right)$, denyut jantung mencapai $79 \mathrm{kali} / \mathrm{menit}$ (Schutz et al., 2009). Ternak yang mengkonsumsi konsentrat dengan tinggi energi (TDN) yang lebih tinggi, memiliki denyut jantung yang cendrung lebih tinggi terutama pada saat cekaman panas.

\section{Suhu rektal}

Keseimbangan produksi panas dan pelepasan panas tubuh. bangsa ternak, aktvifitas ternak, kondisi kesehatan ternak, dan kondisi lingkungan ternak merupakan faktor yang mempengaruhi temperatur tubuh (Frandson, 1996). Pengukuran suhu rektal bertujuan untuk mengetahui suhu dalam tubuh ternak. Blakely dan Bade (1991) menyatakan bahwa meningkatnya suhu rektal dipengaruhi apabila ternak tidak dapat menjaga kondisi suhu tubuhnya melalui pernafasan dan denyut jantung pada saat terjadi perubahan suhu dan kelembaban. Hasil tersebut sejalan dengan penelitian Sulistyowati (1991) bahwa respon fisiologi pada sapi perah meningkat signifikan, sejalan dengan meningkatnya suhu lingkungan, temperatur rektal meningkat dari $38,7^{\circ} \mathrm{C}$ pada suhu lingkungan $26,7^{\circ} \mathrm{C}$, menjadi $38,9^{\circ} \mathrm{C}$ pada suhu lingkungan $27,1^{\circ} \mathrm{C}$, walaupun suhu berbeda $0,2^{\circ} \mathrm{C}$.

Rataan suhu rektal pada saat penelitian tertera pada Tabel 3 berkisar antara $37,96-38,45^{\circ} \mathrm{C}$. Hasil penelitian menunjukkan suhu rektal sapi perah yang dipelihara masih dalam kisaran normal. Kisaran normal suhu rektal pada sapi perah berkisar 38,2-39,1 (Schutz et al.,2009). Hal tersebut mengindikasikan bahwa ternak tidak mengalami stress panas, diduga stress panas telah cukup diantisipasi dengan sistem pengurangan panas oleh tubuh ternak. Churng (2002) mengemukakan bahwa upaya dalammengurangan panas dapat dilakukan, antara lain mengurangi konsumsi pakan, memperbanyak minum, meningkatnya frekuensi respirasi, produksi saliva dan mengeluarkan urin.
Rataan suhu rektal pada pagi dan sore hari, masing-masing berkisar 37,95-37,96 dan $38,08-38,45^{\circ} \mathrm{C}$. Berdasarkan hasil tersebut didapatkan bahwa suhu rektal ternak masih berada dalam kondisi normal walaupun diberi perlakuan pemberian konsentrat kulit durian fermentasi. Subronto (1995) melaporkan bahwa suhu rektal sapi dalam kondisi normal berkisar $38,5^{\circ} \mathrm{C}$ dan suhu kritis berkisar $39,5^{\circ} \mathrm{C}$. Jumlah pemberian konsentrat kulit durian fermentasi yang yang berbeda akan mempengaruhi nafsu makan pada ternak. Meningkatnya kecernaan ransum menyebabkan laju pakan ke organ pasca rumen lebih cepat dan lambung cepat kosong, mendorong ternak untuk terus makan, yang dapat menyebabkan suhu rektal meningkat (Indriati, 2011). Proses termoregulasi atau pengaturan keseimbangan panas melalui mekanisme homeostatis di dalam tubuh merupakan hasil kerja organ-organ tubuh sehingga suhu rektal tetap normal (Purwanto et al., 1993). Rataan suhu rektal pada pagi hari berkisar $37,96^{\circ} \mathrm{C}$ dengan suhu lingkungan $20^{\circ} \mathrm{C}$, peningkatan suhu rektal terjadi pada pengamatan siang hari berkisar $38,45^{\circ} \mathrm{C}$ dengan suhu lingkungan $25^{\circ} \mathrm{C}$.

Peningkatan suhu lingkungan dapat berpengaruh terhadap peningkatan suhu rektal pada ternak sapi perah, sedangkan pada sore hari suhu rektal mengalami penurunan sekitar $38,28^{\circ} \mathrm{C}$ dengan suhu lingkungan sebesar $24^{\circ} \mathrm{C}$. Tingginya suhu udara disebabkan menurunanya laju metabolisme tubuh ternak (Yani dan Purwanto, 2006). Menurunnya laju metabolisme pada tubuh ternak tersebut sebagai upaya mempertahankan mekanisme fisiologi tubuh untuk mencegah peningkatan suhu rectal (Santosa, 2008). Ketika ternak berada dalam kondisi cekaman panas dengan suhu udara yang lebih tinggi dibanding pada suhu udara lingkungan pagi dan sore, maka respon ditandai dengan peningkatan suhu rektal dan meningkatnya denyut nadi, serta laju respirasi (Novianti et al., 2013). 


\section{KESIMPULAN}

Berdasarkan hasil penelitian dapat disimpulkan bahwa pemberian pakan yang mengandung konsentrat kulit durian fermentasi sampai level $30 \%$ tidak berpengaruh pada frekuensi respirasi, denyut jantung, suhu rektal, dan konsumsi bahan kering pakan.

\section{UCAPAN TERIMAKASIH}

Penelitian ini merupakan bagian dari penelitian yang dibiayai oleh DRPM Kemenristek-Dikti melalui skim Strategis Nasional dengan nomor kontrak 052/SP2H/LT/DRPM/2018. Disampaikan penghargaan yang tinggi atas research grant yang diberikan melalui seleksi Nasional. Peneliti juga menyampaikan terimakasih kepada Pak Joko yang telah menyediakan sapi perah untuk penelitian ini. Ucapan terimakasih juga disampaikan kepada Icuk Ramadhani, Ririn Putri, Bogi Al Iman, Aji Prayogi, Enita Terimasari, dan Sistanto SPt. MSi yang telah membantu dalam pelaksanaan penelitian ini.

\section{DAFTAR PUSTAKA}

[BMKG], Badan Meteorologi, Klimatologi, dan Geofisika. 2019. Kondisi Geografis dan Administrasi Menurut Letak Wilayah Kecamatan Kabawetan Kabupaten

Kepahiang.http://www.kepahiangkab.g o.id/index.php/profildaerah/kondisigeo grafis-dan-administras-wilayah. Diakses 17 Januari 2019.

[BPS], Badan Pusat Statistik Propinsi Bengkulu. 2012. Produksi Buah buahan Menurut Kabupaten Kota dan jenis buah di Bengkulu per Kuintal. http://bengkulu.bps.go.id. Diakses tanggal 19 Desember 2017.

[NRC], National Research Council. 1989. Nutrient Requirements of Dairy Cattle. Sixth Revised Edition Update.
Nasional Academy Press. Washington, D. C.

Badarina, I., D. Evvyernie,T. Toharmat, E.N. Herliyana, and L.K. Darusman. 2013. Nutritive Value of Coffee Husk Fermented with Pleurotus ostreatus as Ruminant Feed. Media Peternakan. 361: 58-63.

Beede, D. K. and R.J. Collier. 1986. Potential nutritional strategies for intensively managed cattle during thermal stress. J. Anim. Sci. 62 (1986) 543-554.

Blakely, J and D.H.Bade. 1991. Ilmu peternakan (terjemahan). Edisi ke -4 . Gadjah Mada University Press; Yogyakarta.

Bohmanova, J., I. Misztal, J. B. Cole. 2007. Temperature humidity indices as Indicators of Milk Production Losses due to Heat Stress. J. Dairy Sci. 90: 1947-1956.

Chase, L.E . 2006. Climate Change Impacts on Dairy Cattle. Climate Change and Agriculture: Promoting Practical and Profitable Responses. http://dbcc.onep.go.th/climate/attachme nts/article/105/Climate $\% 20$ Change $\% 20$ Impacts\%20on\%20Dairy\%20Cattle.pdf . Diakses 19 Januari 2019.

Churng, F.L. 2002. Feeding Management and Strategies for Lactating Dairy Cows under Heat Stress. International Training on Strategies for Reducing Heat Stress in Dairy Cattle. Taiwan.

Davies, H. L. 1982. Nutrition and growth. Hedges and bell Pty. Ltd. Melbaurne.

Divers, T. J. dan S. F. Peek. 2008. Rebhun's Diseases of Dairy Cattle. 2nd Ed. Saunders.

Dobson, H, Ghuman S.P.S, Prabhaker S, Smith R.F. 2003. A conceptual model of the Influence of stress on female reproduction. Reproduction. 125:151163. 
Esmay, M.L. 1978. Principle of Animal environmentel. Texbook Ed. AVI Publishing Company, Inc. Wesport, Co. p. 1-15.

Esmay, M.L and Dixon J.E. 1986. Environmental Control for Agricultural Buildings. Connecticut: AVI Publishing Company Inc.

Frandson, R.D.1996. Anatomi dan Fisiologi Ternak. Yogyakarta: Gadjah Mada University Press

Hatakka, A. 1994. Lignin-modifying Enzymes from Selected White-rot Fungi. Production and Role in Lignin Degradation. FEMS Microbiol. Rev. 13: $125-135$.

Indriati, V. 2011. Transit partikel pakan tunggal glirisidia, kaliandra, dan jerami jagung di saluran pencernaan sapi PO dan kerbau. Thesis. Program Pascasarjana Fakultas Peternakan, Universitas Gadjah Mada, Yogyakarta.

Isnaeni, W. 2006. Fisiologi Hewan. Penerbit Kanisius, Yogyakarta.

Johan, M. 2014. Kandungan Nutrisi Baglog Jamur Tiram Puth (Pleurotus ostreatus) sebagai Bahan Pakan Ternak pada Masa Inkubasi yang Berbeda. Skripsi. Fakultas Peternakan. Universitas Hasanuddin. Makassar. http://www.repository.unhas.ac.id diakses pada tanggal 19 Desember 2014.

Larson, B. L. 1985. Lactation. The Iowa State Univ. Press. Ames.

Lentner, M. and T. Bishop. 1986. Experimental Design and Analysis. Valey Book Company. Blacksburg.

Nikkhah, A., C. J. Furedi., A.D. Kennedy., S. L. Scott., K.M. Wittenberg., G.H Crow., and C. Plaizer. 2008. Effects of feed delivery time on feed intake, milk production, and blood metabolites of dairy cows. J. Dairy Sci 9: 4249-4260.
Novianti. J., B.P. Purwanto dan A. Atabani. 2013. Respon Fisiologis dan Produksi Susu Sapi Perah FH pada Pemberian Rumput Gajah (Pennisetum purpureum) Dengan Ukuran Pemotongan yang Berbeda. Jurnal Ilmu Produksi Dan Teknologi Peternakan. 1 (3) : 138146.

Parakkasi, A. 1999. Ilmu Nutrisi dan Makanan Ternak Ruminansia. Jakarta: UI-Press.

Purwanto, B.P., M. Fujita, M. Nishibori, and S. Yamamoto. 1993. Effect of standing and lying behaviours on heat production of dairy heifers differing in feed intake levels. AJAS. 6: 271-274.

Pusbangtepa. 1991. Ragi Tape. Pusat Penelitian dan Pengembangan Teknologi Pangan. IPB. Bogor.

Rumetor, S.D. 2003. Stress Panas pada Sapi Perah Laktasi. Makalah Falsafah Sains. Program Pasca Sarjana. S3. Institut Pertanian Bogor.

Sangadji, I., A. Parakkasi, K. G. Wiryawan, B. Haryanto. 2008. Perubahan Nilai Nutrisi Ampas Sagu pada Fase Pertumbuhan Jamur Tiram Putih. Jurnal Ilmu Ternak. 8 (1): 31-34.

Santoso, U. 2008. Manajemen Usaha Ternak Potong. Penebar Swadaya. Jakarta.

Schutz, K.E., A.R. Rogers., N.R. Cox., C.B. Tucker. 2009. Dairy cows prefer shade that offers greater protection against solar radiation in summer: shade use, behavior, and body temperature. Appl Anim Behav Sci 116 :28-34.

Subronto. 1995. Penyakit Hewan Ternak I. Gadjah Mada Press. Yogyakarta.

Sudono, A, R.F Rosdiana, B.S Setiawan. 2003. Beternak Sapi Perah Secara Intensif. Cetakan ke-2. AgroMedia Pustaka, Bogor.

Suhaidi, I. 2004. Pemanfaatan Limbah Biji Durian sebagai Bahan Pakan Ternak 
Ayam Pedaging. Tesis. Program Pascasarjana. Universitas Sumatera Utara. Medan. http://www.repository.usu.ac.id/bitstrea $\underline{\mathrm{m} / 123456789 / 6603 / 1 / 05000574 . p d f . D i}$ aksestanggal 10 Desember 2014.

Suherman, D., B. P. Purwanto., W. Manalu dan I.G. Permana. 2013. Simulasi Artificial Neural Network untuk Menentukan Suhu Kritis pada Sapi Perah Fries Holland Berdasarkan Respon Fisiologis. Jurnal Ilmu Ternak dan Veteriner. 18. (1): 70-80.

Sulistyowati, E. 1991. Effects of Added Dietary $\mathrm{NaCl}, \mathrm{KCl}$, and $\mathrm{KHCO} 3$ on Production and Physiological Performances of Lactating Dairy Cows during Heat Stress. Thesis University of Kentucky. USA.

Sulistyowati, E., I. Badarina, dan S. Mujiharjo. 2018 ${ }^{\mathrm{a}}$. Milk Production and Feed Efficiency of Dairy Cow Fed Concentrate Containing Durio zibethinus Peel Flour Fermented with Pleurotus ostreatus. Proceeding ISAI $4^{\text {th }}$ Bogor. Indonesia.

Sulistyowati, E., I. Badarina, dan S. Mujiharjo. 2018 . Konsentrat PUFA Curmiyeast Berbasis Kulit Durian Fermentasi Pleurotus ostreatus untuk Memodifikasi Fatty Acid dan Produksi Susu serta Indikator Kesehatan Ternak
Perah. Laporan Akhir Penelitian Strategis Nasional. Kemenristek-Dikti : LPPM. Universitas Bengkulu.

Tucker, C.B., A.R. Rogers, and K.E., Schütz. 2008. Effect of solar radiation on dairy cattle behaviour, use of shade and body temperature in a pasture-based system. Applied Animal Behaviour. Science 109:141-154.

West, J. W. 2003. Effects of Heat-Stress on Production in Dairy Cattle. J. Dairy Sci. 86:2131- 2144.

Widyastuti, N., T. Baruji, R. Giarni, H. Isnawan, P. Wahyudi, dan Donowati. 2011. Analisa Kandungan Beta-glukan Larut Air dan Larut Alkali dari Tubuh Buah Jamur Tiram Putih (Pleurotus ostreatus) dan Shiitake (Lentinus edodes). Jurnal Sains dan Teknologi Indonesia. 13 (3): 182 - 191.

Williamson, G. dan W. J. A. Payne. 1993. Pengantar Peternakan Daerah Tropis. Penerjemah: SGN. D. Darmadja. Gadjah Mada University Press. Yogyakarta.

Yani. A. dan B.P. Purwanto. 2006. Pengaruh Iklim Mikro terhadap Respon Fisiolgis Sapi Peranakan Fries Holland dan Modifikasi Lingkungan untuk Meningkatkan Produktivitasnya. Media Peternakan. 29 (1) : 35-46. 